\title{
Membaca Masyarakat Buton melalui Tradisi Lisan Kabanti Ajonga Yinda Malusa (Pakaian yang Tidak Luntur)
}

\section{La Ode Rabani}

Staf Pengajar di Prodi Ilmu Sejarah, Fakultas Ilmu Budaya, Universitas Airlangga Surabaya, Email: rabani7@gmail.com

\section{IDENTITAS BUKU}

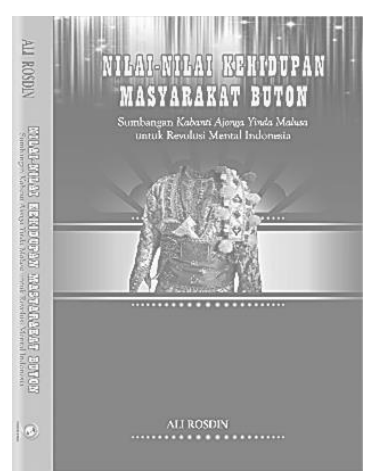

\begin{tabular}{|c|c|}
\hline Judul & $\begin{array}{l}\text { : Nilai-Nilai Kehidupan Masyarakat Buton, } \\
\text { Sumbangan Kabanti Ajonga Yinda Malusa } \\
\text { untuk Revolusi Mental Indonesia }\end{array}$ \\
\hline Penulis & : Ali Rosdin \\
\hline Penerbit & : Oceania press \\
\hline Tebal & : xxiii+491 hlm. \\
\hline Terbit & : 2015 \\
\hline SBN & : 978-602-73717-0-9 \\
\hline
\end{tabular}

Buku hasil karya dari Ali Rosdin yang berjudul Nilai-Nilai Kehidupan Masyarakat Buton, Sumbangan Kabanti Ajonga Yinda Malusa untuk Revolusi Mental Indonesia telah memperkaya khasanah pengetahuan lokal dari beragam dimensi, khususnya yang bersumber dari naskah klasik (lama) yang terkait dengan kehidupan manusia, di ruang geografis yang disebut sebagai "Buton". Ikatan identitas sebagai masyarakat berkarakter khas Buton dalam konteks karya cukup kuat, dan seringkali menjadi "pengikat" di kala masyarakat Buton berada di luar satuan geografisnya. Tidak mengherankan, ketika ikatan identitas itu ditelusuri akarnya, maka jawabannya ada dalam Kabanti Ajonga Yinda Malusa, yang artinya "pakaian yang tidak luntur". Barangkali karakter itu pula yang membuat orang-orang Buton mudah dikenal oleh orang-orang di luar Buton. Keberanian (basmalah), malu (santun), takut, kasih, pelihara, insyaf, dan awine, sikap yang mencitrakan perempuan (Rosdin 2015, 192) adalah sebagaian dari sifat-sikap orang Buton (Udu 2017).

Khusus yang pertama, keberanian, tampaknya tidak diragukan lagi mengingat sejarah panjang sebagian orang-orang Buton ikut menjadi bagian yang mengisi ruang laut Nusantara, baik sebagai nelayan, pedagang antarpulau, pelayar (Rabani 1997), dan sebagian terlibat dalam aktivitas bajak laut. Sebagian orang-orang Buton juga menjadi salah satu yang paling ditakuti oleh orang-orang Eropa (Vlekke 2008). Sebagian besar dari sifat baik orang Buton itu sebagaimana dihadirkan penulisnya dalam buku ini diakui cocok untuk membantu negara yang sedang dilanda "krisis" mental, sehingga perlu gerakan masif untuk mengembalikan kembali sifat-sifat baik masyarakat Indonesia ke rel yang sesuai dengan perkembangan zaman yang maju pesat dan cepat. 
Buku ini mengisi sebagian yang dibutuhkan oleh bangsa Indonesia sebagai "suplemen" penambah energi penyembuh mental anak bangsa yang semakin rapuh, di tengah derasnya tuntutan dan serangan informasi yang serba cepat, khususnya anak bangsa yang lahir dari ruang budaya buku ini. Kearifan lokal dan ajaran nilai sebagaimana yang diungkap buku ini tidak berbeda jauh dengan nilai dan kearifan lokal di daerah lain nusantara. Semuanya bermuara pada penanaman dan pewarisan nilai-nilai budaya yang oleh penganutnya sangat baik untuk dipegang teguh dan diamalkan.

Buku ini ditinjau dari isinya, amat padat (491 halaman dan pengantarnya 13 halaman), termasuk lampiran berupa naskah dan analisis suntingan teksnya. Buku ini merupakan buah dari kerja keras penulisnya ketika menempuh pendidikan Doktor di Universitas Gadjah Mada, Yogyakarta, dalam bentuk Disertasi. Sebagai karya Disertasi, salah satu ciri penandanya dengan mudah dapat ditemukan pada bagian awal buku, misalnya masih ikut sertanya tinjauan pustaka, kajian teori, dan metodologi, meskipun itu sah-sah saja hadir di dalam suatu karya. Akan tetapi, hadirnya bagian-bagian itu memberi kesan bahwa penulis tidak ingin kehilangan konteks dan itu menjadi cara penulis menyatakan kepada pembaca, bahwa buku ini berasal dari proses riset yang ketat. Atas dasar itu, penulisnya memberi garansi, bahwa karyanya benar-benar melalui prosedur kerja ilmiah yang ketat.

Hasil karya Ali Rosdin terdiri dari lima bagian (bab). Bagian pertama merupakan pendahuluan yang menjadi dasar pijakan penelitian. Bagian dua berisi konteks bagaimana Kesultanan Buton menjadi bagian aktif dari tradisi pernaskahan di Nusantara bersama-sama dengan kerajaan lain di Nusantara seperti Aceh, Ternate, dan Minangkabau. Bagian tiga berisi posisi KAYM dalam sastra beserta elemenelemen yang mengikutinya. Pada bagian IV adalah substansi utama berupa penjabaran beragam nilai-nilai karakter khas Buton yang dapat berkontribusi untuk "menyembuhkan" sebagian dari mental anak bangsa yang sedang butuh suplemen. Bagian ini merupakan bagian yang mendapat porsi khusus, karena penulis juga menghadirkan substansi tentang realitas kehidupan masyarakat Buton dan fungsi KAYM dalam masyarakat. Dua bagian pengetahuan yang hadir itu seperti "cermin" karena KAYM hanya akan menjadi sejarah, di mana realitas historisnya hanya bisa dibayangkan. KAYM benar-benar menjadi cermin dan pedoman bagi masyarakat Buton ketika KAYM dengan realitas masyarakat Buton dipersatukan dan diharmonisasi melalui saluran pendidikan di semua level dan ruang-ruang kehidupan.

Seperti biasanya dan kebanyakan dari produksi naskah selalu memiliki tujuan. Tujaun awal adalah dokumentasi nilai-nilai yang harus diketahui oleh masyarakat intern dan dunia di luar mereka. Nilai itu kemudian diajarkan, diterapkan dan kemudian diwariskan dari generasi ke generasi. Untuk memperkuat nilai, maka elemen sufistik, sebagaimana yang umum berlaku dalam naskah-naskah Nusantara selalu disematkan. Penamaan selalu mengikuti nilai terpenting dalam sebuah naskah. penamaan itu terkait erat dengan makna terdalam dari sebuah naskah. Sebagai gambaran, naskah Kabhanti Ajonga Yinda Malusa yang berarti Pakaian yang tidak luntur, jelas mempunyai kekuatan makna. Suryadi menyebutnya sebagai Kilauan dari Buton untuk Indonesia. Artinya, serpihan sinar (bernilai) dari Buton untuk Indonesia (Suryadi 2015). 
Naskah tradisi lainnya juga hampir sama dengan Kabanti yang mengandung beragam nilai untuk kehidupan sesuai konteksnya, Dalam sejarah masyarakat Buton, KAYM lahir di tengah suasana masyarakat yang relatif stabil, di mana perlindungan dan kebebasan diperoleh untuk mengembangkan peradaban tertulis pada medio abad XIX. KAYM lahir pada situasi masyarakat Buton yang sudah semakin religius dan kebiasaan menulis kehidupan di istana dan masyarakatnya sedang menggeliat. Warisan tertulis naskah-naskah Buton (lainnya) adalah bukti atas suasana demikian (beraksara Arab umat Islam semakin banyak). Implikasinya, generasi masa kini masih menikmati warisan pengetahuan dari naskah-naskah klasik itu. Dalam konteks yang sama, penulis buku, Ali Rosdin sedang mengikuti pola yang hampir sama, yakni mewariskan pengetahuan melalui naskah (buku) ilmu pengathuan untuk kita di masa kina dan masa mendatang. Pada titik inilah kontribusi besar buku ini dirasakan.

Andai saja buku ini tidak lahir di arus "project revolusi mental" maka terasa nuansa klasiknya, dari sisi kesan awal membaca judulnya. Judul yang diembel-embel dengan kalimat "untuk Revolusi Mental Indonesia" menurut saya ikut "menjerumuskan" naskah disertasi baik ini dalam kubangan "beraroma marketing", yang saya maksud adalah menyesuaikan dengan selera pasar yang sedang bergeliat. Pada titik itulah masalahnya, di satu sisi karya ini ingin memenuhi dahaga atas "kegoyahan" nilai-nilai kehidupan masyarakat Buton, dan pada sisi yang lain, harus mengikatkan diri dengan arus keinginan negara yang ingin segera menyehatkan mentalitas warganya. Akibatnya, dua keinginan itu sulit dipertautkan, di mana standing position buku ini tidak tampak di tengah buku-buku sejenis.

Terlepas dari sejumlah kelemahan kecil buku ini saya setuju dengan Suryadi, dalam pengantarnya bahwa Ali Rosdin telah menghadirkan 'Mutiara yang Berkilau' dari Buton untuk Indonesia. Ada beberapa alasan yang dikemukakan untuk mendukung penilaian tersebut. Namun yang paling penting di antaranya adalah naskah klasik yang dikaji penuh dengan ajaran moral, keagamaan, dan sampai batas tertentu, menjadi catatan sejarah. Hal penting lainnya adalah penulis telah bekerja keras melalui prosedur ilmiah dengan menerjemahkan dan menyunting teks Kabanti Ajonga Yinda Malusa (KAYM) ke dalam sebuah media yang usianya melampau usia manusia (xxii-xxiii).

Selamat membaca!

\section{REFERENSI}

Rabani, La Ode. 1997. "Migrasi dan Perkembangan Sosial Ekonomi Masyarakat Kepulauan Tukang Besi Kabupaten Buton 1961-1987." Yogyakarta: Universitas Gadjah Mada.

Rosdin, Ali. 2015. “Nilai-Nilai Kehidupan Masyarakat Buton: Kajian Filologi Dan Sosiologi Sastra Serta Suntingan Teks Dan Terjemahan Terhadap Naskah Kabanti Ajonga Yinda Malusa." Yogyakarta: Universitas Gadjah Mada. 
Suryadi, Suryadi. 2015. “Kabanti Ajonga Yinda Malusa: 'Mutiara Berkilau' dari Buton Untuk Indonesia." In Nilai-Nilai Kehidupan Masyarakat Buton, Sumbangan Kabanti Ajonga Yinda Malusa, xi-xxiii. Kendari: Oseania Press.

Udu, Sumiman. 2017. "Wowine Dalam Kebudayaan Maritim Wakatobi Buton: Analisis Pierre Bourdieu." SASDAYA: Gadjah Mada Journal of Humanities 2 (1): 267-82.

Vlekke, Bernard Hubertus Maria. 2008. Nusantara: Sejarah Indonesia. Jakarta: Kepustakaan Populer Gramedia. 